\title{
Enhancing graduate employability and the need for university- enterprise collaboration
}

\author{
Thi Tuyet $\operatorname{Tran}^{1}$ \\ thi-tuyet.tran@iab.de \\ ${ }^{1}$ Institute for Employment Research, \\ German Federal Employment Agency
}

\begin{abstract}
Over the last few decades there has been strong debate over the central mission of higher education and resistance to the employability agenda seemed strong. However, with the changing context of both higher education and the labour market, together with neoliberal pressure, enhancing graduate employability has become one of the central focuses in many universities worldwide.

This article provides an overview of the relevant literature to resonate with why graduate employability has been more popularly presented in many university practices. The notion of graduate employability is examined and it is argued that without input from and collaboration with industry, universities are hardly able to achieve their vocational mission of equipping their students for the labour market.
\end{abstract}

Keywords: graduate employability, higher education, labour market, university-enterprise collaboration

\section{Introduction}

Higher education (HE) has increasingly been tied to the needs of the economy and society. From developed countries to developing countries, there is a loud call to make university education more relevant to the workplace. There seem to be fewer debates over the central mission of $\mathrm{HE}$, with universities tending to accept neoliberal pressure and looking for ways to make their educational practices more aligned with the needs of the labour market. Enhancing graduate employability has become one of the central focuses in many universities worldwide. Collaboration between universities and enterprises in different ways has been reported as valuable in order to 'bring the labour market' into the classroom.

This paper provides an overview of the relevant literature to explore the reason why graduate employability - an 'add-on' mission for some academics and the 'subset' of a mission for the others (Harvey, 2000, p. 4; Speight, Lackovic, \& Cooker, 2012), has been popularly presented in many university practices. The notion of graduate employability is examined and it is argued that without input from and collaboration with industry, universities are hardly able to strengthen their vocational mission of equipping students for the labour market.

\section{The changing context of $\mathrm{HE}$ and the need to enhance graduate employability}

It has been argued that HE has always met its social and economic obligation and this is tacitly achieved through academics' professional understanding of social and economic needs (Boden \& Nedeva, 2010). However, there has been an increasingly neoliberal pressure on HE 
to make explicit the task of preparing students with the knowledge and skills required by the contemporary labour market. Several developments have led to this situation.

First, mass HE creates many internal changes within the sector. The number of students is booming. On the one hand, gaining access to HE is no longer privileged or difficult; on the other hand, government funding for $\mathrm{HE}$ is decreasing, with students increasingly having to pay for their study. Furthermore evidence suggests that employability is increasingly important in students' choice of institutions (Artess, Forbes, \& Ripmeester, 2011). At the same time global mass HE has created a crowded labour market (Tomlinson, 2012). This challenges the traditional mission of HE which was to prepare the elite to govern the nation, to the need to provide an institutional basis for research into all forms of knowledge (Jarvis, 2002, p. 43), and to facilitate access to desired forms of employment (Scott, 2005). HE credentials are no longer a sufficient condition for obtaining employment, let alone a desired form of employment. HE institutions are beginning to recognise that there are concerns around accommodating employability for their graduates, and have gradually taken up this challenge (Rosenberg, Heimler, \& Morote, 2012).

The changes resulting from mass HE have been coupled with changes in the labour market in more recent decades. The spread of globalisation and of neoliberal policies has encouraged the restructuring of the economy around competition and efficiency, resulting in downsizing, delayering and restructuring of organisations. Fewer people are required for the same job, and more tasks are required to be managed by each person. The new world of work requires skills such as negotiating, networking, problem solving, and skills to manage processes rather than just functional skills (Evans, 2008). Also increasingly expected are multi-skilled and multitasking employees (Foss \& Laursen, 2005). This was not the traditional focus of HE. Thus, the sector is expected to be responsive towards the new needs of the economy, to provide ample opportunities for their students to develop knowledge, skills and to nurture their capability for life-long learning (Harvey, 2000).

Universities are under pressure to take on-board employability, not only as a pragmatic response (Clarke, 2008) to the competition among universities, but also to the requirements of society. In most cases, universities also need to satisfy the requirements and the expectations of the neoliberal governments. Policy-makers tend to tie HE institutions to the needs of the economy and the society (European Commission, 2003, 2005, 2011). In the UK for example, the government has increasingly exerted pressure on the HE system to enhance outputs, quality and their overall market responsiveness (Department for Education, 2010). There is an explicit expectation from the government that HE institutions are able to provide graduates who can readily adapt to their working environment and are adaptable within it (Cable, 2010).

Similarly, in the USA, an employability skills agenda has been developed with direct involvement from the government and the National Association of Colleges and Employers (NACE), the body responsible for publishing detailed professional standards for college and university career services. With the aim of assisting the USA industries to retain their competitive edge, the Secretary's Commission on Achieving Necessary Skills (SCANS) ${ }^{1}$ was established in 1990 to report the basic skills required for workers. In Europe, the Bologna Process $^{2}$ which prioritises employability among other HE objectives has created pressure as well as opportunities for HE to shift its identity towards an economic rationale (Tomusk, 2004). Up until recently, 50 countries with more than $4000 \mathrm{HE}$ institutions had adapted their HE systems following the Bologna process (Bologna Process, 2016).

\footnotetext{
${ }^{1} \mathrm{http}: / /$ wdr.doleta.gov/SCANS/

2 The Bologna Process is a series of ministerial meetings and agreements between European countries designed to ensure comparability in the standards and quality of higher education qualifications.
} 
Not only are universities in the developed world under pressure to take on-board employability, universities in much less developed countries in South East Asia are also struggling to adapt to the new requirements and expectations from their governments. Recently, 30 universities from 10 countries (including Brunei, Cambodia, Laos, Indonesia, Malaysia, Myanmar, Singapore, the Philippines, Vietnam and Thailand) have become members of the ASEAN University Network (AUN) and followed the AUN quality assurance framework (QA) (ASEAN University Network, $2015^{3}$ ). The ASEAN member countries also developed their own quality assurance framework following the AUN-QA and requested that all universities in the AUN system follow those 'standards'. The framework requires universities to work closely with employers from developing the curriculum, to revising the syllabus and then to the employment process of the students. The focus on outcomes (such as the ratio of graduates gaining employment after graduation) also drives universities to take into account the demands of employers in their academic practices.

Clearly, both internal and external contexts have placed graduate employability high on the policy agenda in most HE sectors worldwide. The argument over who should take responsibility to develop graduate employability (Tran Thi Tuyet, 2015) does not seem to be crucial as the focus of the discussion is now on how to best enhance graduate employability. In the following section, the dialogue surrounding the concept of employability is reviewed.

\section{What is graduate employability?}

Although employability is in vogue in the HE context, there is no common definition of it in the literature. Some studies focus more on individual student ability to get and retain a job after graduation and as such define employability as follows:

...the capacity to gain initial employment, maintain employment and obtain employment if required (Hillage \& Pollard, 1998, p. 2), or

... the ability of graduates to find and retain a graduate-level job and also the ability to move between jobs if required (Yorke, 2010).

In fact, the majority of the most popular definitions do not mention the stakeholders who need to be in charge of, or involved in, graduate employability. Rather, employability is defined as the types of skills, knowledge, attributes or understandings, as seen in the following examples:

... a set of achievement - skills, understandings and personal attributes - that makes graduates more likely to gain employment and be successful in their chosen occupations, which benefits themselves, the workforce, the community and the economy (The Enhancing Student Employability Co-ordination Team - ESECT (Yorke, 2006, p. 8).

...a set of skills, knowledge and personal attributes that makes an individual more likely to secure and be successful in their chosen occupations to the benefit of themselves, the workforce, the community and the economy (Moreland, 2006).

...skills required not only to gain employment, but also to progress within an enterprise so as to achieve one's potential and contribute successfully to enterprise strategic directions (Australian Chamber of Commerce and Industry \& Business Council of Australia, 2002).

...the skills almost everyone needs to do almost every job. They are the skills that must be present to enable an individual to use more specific knowledge and technical skills that their particular workplaces will require (UK Commission for Employment and Skills, 2009).

\footnotetext{
${ }^{3}$ http://www.aunsec.org/aunmemberuniversities.php
} 
Artess, Forbes and Ripmeester (2011) suggest that while the term 'employability' may not always be used, there is an underlying consensus as to what employability comprises - a range of specific, employment-related skills or attributes (hard and soft skills) relevant to acquiring and succeeding in employment.

Although different in wording, these definitions all relate employability to a set of skills and/or attributes that are necessary for any graduate to move into the employment market, to find and retain jobs and to develop his/her career.

The question then becomes what are those skills/attributes, apart from the knowledge (hard skills), that are traditionally the domain of the universities? Again, one can find different concepts of skills used in the literature which all claim to be necessary for graduates to participate and to develop in the employment market: generic skills, soft skills, transferable skills, cross-disciplinary skills, graduate attributes, core skills, key skills, basic skills, crosscurricular skills, common skills, essential skills, enterprise skills or even employability skills, to name a few (Caballero, Walker, \& Fuller-Tyszkiewicz, 2011; Cabellero \& Walker, 2010; Hager \& Holland, 2006; Lowden, Hall, Elliot, \& Lewin, 2011; Rust \& Froud, 2011). The word 'skills' appears in almost all articles in relation to the quality outcomes of HE; professional knowledge is sometimes also considered a type of skill, called technical skills (AC Nielsen Research Services, 2000; World Bank, 2011). Nonetheless, the professional knowledge or students' technical skills are differentiated from generic skills. While technical skills often refer to discipline-based skills and capacity, generic skills (and its equivalent terms), as described by Andrews and Higson (2008), cover such areas as coping with uncertainty, working under pressure, planning and strategic thinking, reliability, communications and interpersonal interactions, teamwork and networking, writing and speaking, information technology skills, creativity, self-confidence, self-management and time-management, willingness to learn and acceptance of responsibility. In a project which reported to The Australian Chamber of Commerce and The Industry and Business Council of Australia, generic employability skills were identified as more 'simple' skills which included communication, teamwork, problem solving, initiative and enterprise, planning and organisation, self-management and learning and technology skills (ACER, 2002).

These skills are increasingly viewed as important, not only for graduates and not only in an employment context. They are viewed as increasingly important in the changing context of contemporary life. Nonetheless, these skills are essential in the employment context and are considered important to make graduates prepared or ready for success in today's rapidly changing work environment' (Cabellero \& Walker, 2010, p. 16).

\section{The need for university-enterprise collaboration (UEC)}

Paradoxically, not all of these skills can be developed solely in the HE context. Initiative and enterprise skills, planning and strategic thinking and working under pressure are examples of such skills. Moreover, different stakeholders (such as employers, academics and students) may view these skills differently, and indeed research has reported the mismatch between stakeholders' perceptions of these skills (Handel, 2003; Sala, 2011; Tran Thi Tuyet, 2012). Nonetheless, when these skills are viewed as necessary for graduates to get and retain jobs, employers' voices become powerful. Interestingly, while university is seen as the place to develop students' employability, the results of that development can only be seen in enterprises. Moreover the skills helping graduates to retain jobs and to develop in their careers will mainly be developed in the working context. Evidence suggests that employers value innovative, adaptable, resilient graduates with flexible enterprise skills, an enterprising mindset and business awareness, which are mainly the outcome of enterprise learning (Owens \& 
Tibby, 2014; Weligamage, 2009). Clearly, if the HE sector adopts employability goals then input and collaboration from industry is essential.

There is another reason fundamental to universities and enterprises collaborating to enhance graduate employability: that is the need of industry for prospective employees to be workready in specific disciplines. Enterprises are now under pressure to increase productivity in a competitive global market. Moreover, with an exuberant pool of skilled workers (as a result of mass HE), employers have become more selective in their choice, and their requirement for work experience often appears unreasonable for recent graduates (Tran Thi Tuyet, 2014). Getting familiar with the working culture, gaining practical knowledge in the workplace, knowing how to apply what has been learnt in practice, are some of the HE practices helping students satisfy this requirement of employers. However, these practices all require input from and cooperation with enterprises. It is not surprising the literature on graduate employability has overwhelmingly focused on different forms of cooperation between universities and enterprises and highlighted that employers, students, graduates and HE institutions value work-based learning and work integrated learning as particularly effective approaches to promote the employability of graduates (Etzkowitz, 2004; Lowden et al., 2011, p. VI; World Bank, 2012).

\section{Different types of UEC}

The literature suggests that there are different ways for university industry interaction to occur; nonetheless, the traditional focus of UEC has remained on knowledge transfer and innovation (Bruneel, d'Este, \& Salter, 2010; Gertner, Roberts, \& Charles, 2011; O'Leary, 2013). Discussion of the need for close UEC to enhance graduate employability has recently emerged as a result of neoliberal government pressure and the importance of employability to university applicants (Wilson, 2012). In the last decade, UEC practices aimed at enhancing the work-readiness of university students developed quickly and are referred to in different terms such as work integrated learning or cooperative education. All of these practices share a common aim of connecting theory to practice, and they come in many forms such as work placements, internships, guest speakers, recruitment drives or practical projects of various types. Generally these initiatives indicate the responses from both sides: universities and enterprises. Some forms of UEC have seen universities 'go out' (Blackmore, Bulaitis, Jackman, \& Tan, 2016) into the workplace, sending academic staff and students to enterprises for practical lessons. These may be through collaboration for research and development (for academics) or through internships, placements or conducting real life projects (for students). And indeed, student mobility activities (e.g. student internship/placement) are often reported in the literature to be the most popular form of UEC to enhance graduate employability. These initiatives also indicate the employers' efforts in offering students places for internships and placements. Some other types of UEC reveal the efforts of employers/enterprises to engage in university practices. This might be, for example, employer involvement in curriculum development, in student assessment, or in recruiting students. Other forms of collaboration/partnership between universities and industry have emerged to provide sandwich courses or degree programs in different formats. This blurs the barriers between the academic world and the world of work. Table 1 summarises the major forms of UEC for enhancing graduate employability. 
Table 1: Types of UEC for Enhancing Graduate Employability

\begin{tabular}{|c|c|c|}
\hline & Types of UEC & Notes \\
\hline \multirow[t]{5}{*}{ Universities going out } & Student work placements & \multirow[t]{3}{*}{ Mobility of students } \\
\hline & Student internships & \\
\hline & $\begin{array}{l}\text { Students conducting real life } \\
\text { projects in firms }\end{array}$ & \\
\hline & $\begin{array}{l}\text { University } \\
\text { academics/managers } \\
\text { experience the work in firms }\end{array}$ & \multirow[t]{2}{*}{ Mobility of academics } \\
\hline & $\begin{array}{l}\text { University training for } \\
\text { enterprises' orders }\end{array}$ & \\
\hline \multirow{9}{*}{$\begin{array}{l}\text { Enterprise engagement in } \\
\text { university practices }\end{array}$} & Employer involvement in: & \multirow{9}{*}{$\begin{array}{l}\text { Employers' involvement in } \\
\text { curriculum development } \\
\text { and delivery }\end{array}$} \\
\hline & Curriculum development & \\
\hline & Degree advisory board & \\
\hline & Student assessment & \\
\hline & Guest lectures & \\
\hline & Student mentoring & \\
\hline & Career fairs or events & \\
\hline & Sponsorships/ scholarships & \\
\hline & Graduate recruitment & \\
\hline \multirow[t]{3}{*}{$\begin{array}{l}\text { Universities and firms } \\
\text { collaborate to deliver }\end{array}$} & $\begin{array}{l}\text { Work based learning degree } \\
\text { programs/sandwich years }\end{array}$ & \\
\hline & $\begin{array}{l}\text { Research and development } \\
\text { activities }\end{array}$ & \\
\hline & $\begin{array}{l}\text { Practical projects either on } \\
\text { university campus or in } \\
\text { enterprises }\end{array}$ & \\
\hline
\end{tabular}

Sources: Confederation of British Industry (2013); Davey, Baaken, Galan Muros and Meerman (2011) and Hogarth et al.(2007)

\section{Benefits brought about by UEC}

The most obvious advantage of the above forms of UEC is the blending of the professional knowledge students acquired at university with authentic application of that knowledge in the workplace. Most universities' student and staff mobility initiatives work for the same aim: to expose participants to authentic and relevant contexts at workplaces where they can apply theory to practice. By joining the world of work, academics can enrich their understanding about the real practices and develop more responsive teaching syllabi, with the final aim being to provide students with more practical lessons both in and out of the university context. In other words, UEC enhances experiential learning, which helps and also requires students to integrate theory and practice (Cooper, Orrell, \& Bowden, 2010; Ferns, Campbell, \& Zegwaad, 2014; Ferns \& Moore, 2012; Smith, Meijer, \& Kielly-Coleman, 2010). In these ways, UEC provides students with opportunities to reflect on the knowledge they have learnt in the university context and apply that knowledge in practices at work to solve the real world 
problems (Patrick et al., 2008; Weisz \& Smith, 2010). Similarly, the involvement of employers in university practices, such as their engagement in course design or in delivery of lectures, also improves the relevance of the lessons delivered for students. The partnership between university and industry in any form, somehow connects the academic discipline knowledge and the real experience at work, which has been seen by some, as contradictory. Nonetheless, it is argued that the experience of professional life does promote knowledge development (Ferns \& Moore, 2012; Fry, Ketteridge, \& Marshall, 2005). In other words, UEC provides students with opportunities to connect skills and knowledge from different sources and experiences, to apply theory to practice in various settings, to appreciate diverse points of view and understand issues and positions contextually (Huber \& Hutchings, 2004).

The collaboration and partnership between university and industry to provide educational programs which combine and integrate learning and workplace application, provides students with valuable opportunities to learn the tacit knowledge at work, and thus, enhance their employability. It has been reported that one of the most difficult problems students experience in the transition from university to work is to learn the tacit knowledge at the workplace (Beckett \& Mulcahy, 2006; Sternberg et al., 2000). This knowledge is needed for students to successfully adapt to, select, or shape the real world environment (Sternberg et al., 2000, p. 104). Although this knowledge has nothing to do with the level of educational attainment students reach, it is suggested that schools and universities can provide guidance and intervention to develop occupational knowledge and skills (Artess et al., 2011; Chapple \& Tolley, 2000; Creed, Muller, \& Patton, 2003; Harvey, 2005; Helyer, Lee, \& Evans, 2011; Lowden et al., 2011; Rust \& Froud, 2011). One of the best ways to achieve this is to put students in the real context of work, to learn and to develop their own understanding about this tacit knowledge.

Similarly, UEC which provides students with opportunities to be exposed to the real world of work, can help students develop skills in meaningful ways. The language of skills sometimes appears overlapping and confusing, and is criticised for being unable to capture elements of knowledge which remain specific and tacit (Beckett \& Mulcahy, 2006; Tran Thi Tuyet, 2014; Winch, 2006). Numerous advantages of work integrated learning for skill development have been reported in the literature: it improves students' critical thinking skills, time management skills, decision making skills, teamwork and organisational skills. It also enhances their adaptability and specific discipline skills, as well as broader transferable skills (Eames \& Cates, 2011; Ferns et al., 2014; Fleming \& Eames, 2005; Smith et al., 2010).

By integrating theory and practice and creating opportunities for students to learn the tacit knowledge and work related skills during their university program, the collaboration between university and enterprise has provided students with opportunities to master their professional knowledge in their specific disciplines and become familiar with organisational practices at the same time. This improves the work readiness and competitiveness of students entering the world of work after graduation. When students participate in work integrated learning programs they may be better prepared to satisfy the new 'picky' requirements of employers in the labour market. The experience students are able to gain during placements, internships or real life projects also helps them to make better informed decisions about their career choice and path (Zegwaard \& Coll, 2011). In other words, it helps students to shorten their transition from university to employment (Elder, 2014; Tran Thi Tuyet, 2014).

The collaboration between universities and enterprises is reported to bring benefits for not only students, but also educational institutions, employers and the whole industry. As universities connect with the world of work and provide authentic opportunities for students, they become more responsive to industry and students' expectations. This, on one hand, helps universities satisfy the requirements of the neoliberal governments, and on the other hand, improves a university's image in competition for students (Cooper et al., 2010). The collaboration to enhance graduate employability is also reported to open up other opportunities 
for universities and enterprises in research and development (Ferns et al., 2014). Moreover, the close partnership with industry also provides chances for universities to revise and reflect on their curriculum and practices in more responsive ways. By providing universities and students access to the enterprise working context, employers are also giving themselves not only an opportunity to open up other collaborations with universities, but also access to a short term technical labour pool at low or no cost, exposure to fresh and different ideas, and the opportunity to recruit high quality graduates before graduation (Tanaka, 2009). Furthermore, many employers consider the collaboration as a way to increase their social responsibility and to improve their corporate image. Ultimately, the collaboration between universities and enterprises aimed at connecting theory and practice helps to increase productivity, efficiency and effectiveness for the industry and increase the competitiveness of the whole economy in the international market.

\section{Challenges for UEC}

UEC is reported to be an important and effective way to help universities to enhance their graduate employability, and the collaboration is intended to bring benefits for not only students and graduates, but also for the stakeholders, universities and enterprises. However, developing an effective collaboration requires effort from both sides and a positive outcome or impact does not happen by accident (Cooper et al., 2010). Both universities and enterprises need to overcome many challenges in order to develop a workable partnership to help students effectively integrate theory to practice. Some of the major challenges are discussed below.

The most significant challenge for both sides is the requirement for them to step out of their comfort zone. As learning at a workplace is socially distributed, co-produced and legitimized by worker-learners and academics (Choy \& Delahaye, 2011, p. 159), this requires a shift in university culture, from delivering the model/program to enabling the partnership (Harvey, 2007). In order to ensure knowledge is integrated into the workplace, universities need to place equal value on theoretical knowledge and practical knowledge (Orrell, 2011). This is an uncomfortable challenge for universities. Similarly, the collaboration with universities to provide practical lessons for students also requires employers to understand the curriculum and pedagogy of their partner universities. Together they need to create authentic case studies, role plays and scenarios which articulate the scope, nature and standard of required skills to students' (Jackson, 2015, p. 362). When most employers in modern society are 'time poor', being out of their comfort zone like this requires much time and effort; this is a real challenge for them.

The development of a work integrated learning curriculum and assessment is another significant challenge, especially for universities, because it may reduce their autonomy. The curriculum needs to be designed to support the learning for both declarative knowledge, which is the information passed in books and lectures about theory, and functional knowledge, or the application of the theoretical knowledge in a real world situation (Billett \& Choy, 2012; Cooper et al., 2010). The challenge in developing curriculum is similar to the challenge of developing assessment practices which requires the shared input of both universities and enterprises. Designing assessment of students' performance in practical settings in not easy, as the assessment of the process in which students turn tacit knowledge into explicit knowledge and integrate conceptual knowledge and practical experience is difficult and is absent from the literature (Tynjälä, 2008, p. 140). Shifting curriculum and assessment this way is both disagreeable and difficult for universities.

Another problem that both universities and enterprises need to tackle is how to devote quality time to support students to acquire both declarative knowledge and functional knowledge through the work integrated learning curriculum. Positive outcomes can only be expected if sufficient preparation, assistance and support for students before, during and after work

Tran, Thi Tuyet (2016). Enhancing graduate employability and the need for university-enterprise collaboration. Journal of Teaching and Learning for Graduate Employability, 7 (1), 58-71. 
integrated learning experiences is provided (Billet, 2011; Coll et al., 2009). Universities need to provide students with guidance, introduction and understanding about workplace and workplace requirements. Enterprises also need to provide students with suitable induction, training, a positive learning environment, guidance and mentoring (Peach, Larkin, \& Ruinard, 2012). These can only be achieved through a strong partnership between universities and enterprises (Choy \& Delahaye, 2011; Cooper et al., 2010; Ferns et al., 2014; Patrick et al., 2008; Peach et al., 2012). It also requires mutual understanding about each other's practices in order to design appropriate programs and to provide prompt support for students during the process of integrating theory to practice.

\section{Conclusion}

Clearly the collaboration or the partnership between educational institutions and workplaces has proved to be a practical way to increase university responsiveness for the economy, to bring authentic lessons from the market into the university curriculum, to enhance skills desired by contemporary employers, and thus, to enhance employability for students and graduates. UEC is also reported to bring benefits for not only students and graduates, but also for universities, enterprises and the overall society. Nonetheless, the development and implementation of a sustainable and effective collaborative activity/program to enhance graduate employability has brought many challenges for both universities and enterprises. It takes them out of their comfort zone, requires them to develop understandings about each other, to change their routine practices, and to set aside time, effort, human resources and investment to develop and support UEC initiatives. Developing partnerships means that diverse interests and expectations are represented. In order to develop effective collaboration, strengths and threats need to be identified, and a common goal which addresses mutual benefits to all stakeholders needs to be developed. Both partners need to work collaboratively toward the common goal. The integration of theory and practice will only be enhanced when strategies are adequately resourced and well prepared for all, not only students, but also employers and university coordinators. This can only be achieved through a close partnership between universities and workplaces (Choy \& Delahaye, 2011; Cooper et al., 2010; Ferns et al., 2014; Patrick et al., 2008; Peach et al., 2012). 


\section{References}

AC Nielsen Research Services. (2000). Employer satisfaction with graduate skills: Research report. Canberra: Department of Education, Training and Youth Affairs.

Andrews, J., \& Higson, H. (2008). Graduate employability, 'soft skills' versus 'hard'. Business knowledge: A European study. Higher education in Europe, 33(4), 411-422.

Artess, J., Forbes, P., \& Ripmeester, N. (2011). Supporting graduate employability: HEI practice in other countries. BIS Research Paper Number 40. London: BIS.

ACER (2002). Employability skills for the future. Canberra: Department of Education, Science and Training.

Beckett, D., \& Mulcahy, D. (2006). Constructing professionals' employ-abilities: Conditions for accomplishment. In P. Hager \& S. Holland (Eds.), Graduate attributes, learning and employability (pp.243-265). Dordrecht, The Netherlands: Springer.

Billet, S. (2011). Curriculum and pedagogical bases for effectively integrating practice-based experiences. Strawberry Hills, NSW: Australian Learning and Teaching Council (ALTC).

Billett, S., \& Choy, S. (2012). Learning through work: Emerging perspectives and new challenges. Journal of Workplace Learning, 25(4), 264-276.

Blackmore, P., Bulaitis, Z. H., Jackman, A. H., \& Tan, E. (2016). Employability in higher education: A review of practice and strategies around the world. London: Pearson.

Boden, R., \& Nedeva, M. (2010). Employing discourse: Universities and graduate 'employability'. Journal of Education Policy, 25(1), 37-54.

Bologna Process. (2016). Members - Bologna Process - European Higher Education Area. Retrieved 6th September 2016, from: http://www.ehea.info/members.aspx

Bruneel, J., d'Este, P., \& Salter, A. (2010). Investigating the factors that diminish the barriers to university-industry collaboration. Research Policy, 39(7), 858-868.

Caballero, C. L., Walker, A., \& Fuller-Tyszkiewicz, M. (2011). The work readiness scale (WRS): Developing a measure to assess work readiness in college graduates. Journal of Teaching and Learning for Graduate Employability, 2(2), 41-54.

Cabellero, C. L., \& Walker, A. (2010). Work readiness in graduate recruitment and selection: A review of current assessment methods. Journal of Teaching and Learning for Graduate Employability, 1(1), 13-25.

Cable, V. (R.Hon) (2010). A new era for universities. Speech delivered by the Secretatry of State on Higher Education. UK: Department for Business, Innovation \& Skills.

Chapple, M., \& Tolley, H. (2000). Embedding key skills in a traditional university. In S. Fallows \& C. Steven (Eds.), Integrating key skills in higher education (pp.67-76). London: Kogan Page Limited.

Choy, S., \& Delahaye, B. (2011). Partnerships between universities and workplaces: Some challenges for work-integrated learning. Studies in Continuing Education, 33(2), 157172.

Clarke, M. (2008). Understanding and managing employability in changing career contexts. Journal of European Industrial Training, 32(4), 258-284.

Coll, R., Eames, R., Paku, L., Lay, M., Hodges, D., Bhat, R., . . Martin, A. (2009). An exploration of the pedagogies employed to integrate knowledge in work-integrated learning. Journal of Co-operative Education and Internship, 43(1), 14-35.

Confederation of British Industry (CBI) (2013). Changing the pace: $\mathrm{CBI} /$ Pearson education and skills survey 2013. London: Confederation of British Industry. 
Cooper, L., Orrell, J., \& Bowden, M. (2010). Work integrated learning: A guide to effective practice. New York: Routledge.

Creed, P. A., Muller, J., \& Patton, W. (2003). Leaving high school: The influence and consequences for psychological well-being and career-related confidence. Journal of Adolescence, 26(3), 295-311.

Davey, T., Baaken, T., Galan-Muros, V., \& Meerman, A. (2011). Study on the cooperation between higher education institutions and public and private organisations in Europe. Brussels: European Commission, DG Education and Culture.

Department for Education. (2010). Securing a sustainable future for higher education (The Browne Review). London: HMSO.

Eames, C., \& Cates, C. (2011). Theories of learning in cooperative and work-integrated education. In R. K. Coll \& K. E. Zegwaard (Eds.), International handbook for cooperative and work-integrated education (2nd Ed) (pp. 41-52). Lowell, MA: World Association for Cooperative Education Inc.

Elder, S. (2014). Labour market transitions of young women and men in Asia and the Pacific. Geneva: International Labour Office.

Etzkowitz, H. (2004). The evolution of the entrepreneurial university. International Journal of Technology and Globalisation, 1(1), 64-77.

European Commission. (2003). The role of the universities in the Europe of knowledge. Brussels: European Commission.

European Commission. (2005). Mobilising the brainpower of Europe: Enabling universities to make their full contribution to the Lisbon Strategy. Brussels: European Commission.

European Commission. (2011). Supporting growth and jobs - An agenda for the modernisation of Europe's higher education systems. Brussels: European Commission.

Evans, C. (2008). Developing career management skills within the HE curriculum: A review and evaluation of different approaches. The International Journal of Management Education, 6(3), 45-55.

Ferns, S., Campbell, M., \& Zegwaad, K. (2014). Work integrated learning. In S. Ferns (Ed.), HERDSA Guide: Work integrated learning in the curriculum (pp. 1-6). NSW: Higher Education Research and Development Society of Australasia.

Ferns, S., \& Moore, K. (2012). Assessing student outcomes in fieldwork placements: An overview of current practice. Asia-Pacific Journal of Cooperative Education, 13(4), 207224.

Fleming, J., \& Eames, C. (2005). Student learning in relation to the structure of the cooperative experience. Asia-Pacific Journal of Cooperative Education, 6(2), 26-31.

Foss, N. J., \& Laursen, K. (2005). Performance pay, delegation and multitasking under uncertainty and innovativeness: An empirical investigation. Journal of Economic Behavior \& Organization, 58(2), 246-276.

Fry, H., Ketteridge, S., \& Marshall, S. (2005). A handbook for teaching and learning in higher education: Enhancing academic practice (3rd ed.). New York: Routledge.

Gertner, D., Roberts, J., \& Charles, D. (2011). University-industry collaboration: A CoPs approach to KTPs. Journal of Knowledge Management, 15(4), 625-647.

Hager, P., \& Holland, S. (2006). Graduate attributes, learning and employability. Dordrecht, The Netherlands: Springer.

Handel, M. J. (2003). Skills mismatch in the labor market. Annual Review of Sociology, 135165. 
Harvey, L. (2000). New realities: The relationship between higher education and employment. Tertiary Education and Management, 6, 3-17.

Harvey, L. (2005). Embedding and integrating employability. New Directions for Institutional Research (128), 13-28.

Harvey, M. (2007). The changing power balance between learners, universities and work contexts. In D. Young \& J. Garnett (Eds.), Work-based learning futures. Proceedings from the work-based learning futures conference, Buxton, 2007. UK: University of Derby and Middlesex University.

Helyer, R., Lee, D., \& Evans, A. (2011). Hybrid HE: Knowledge, skills and innovation. Work Based Learning e-Journal, 1(2), 18-34.

Hillage, J., \& Pollard, E. (1998). Employability: Developing a framework for policy analysis. London: Department for Education and Employment.

Hogarth, T., Winterbotham, M., Hasluck, C., Carter, K., Daniel, W., Green, A. E., \& Morrison, J. (2007). Employer and university engagement in the use and development of graduate level skills. UK: Institute for Employment Research, University of Warwick: IFF Research Ltd.

Huber, M. T., \& Hutchings, P. (2004). Integrative learning: Mapping the terrain. The academy in transition. Washington, DC: Association of American Colleges and Universities and the Carnegie Foundation for the Advancement of Teaching.

Jackson, D. (2015). Employability skill development in work-integrated learning: Barriers and best practices. Studies in Higher Education, 40(2), 350-367.

Jarvis, P. (2002). The changing university: Meeting a need and needing to change. Higher Education Quarterly, 54(1), 43-67.

Lowden, K., Hall, S., Ellio, D. D., \& Lewin, J. (2011). Employers' perceptions of the employability skills of new graduates. London: Edge Foundation.

Moreland, N. (2006). Entrepreneurship and higher education: An employability perspective. Heslington, York: Enhancing Student Employability Co-ordination Team, ESECT.

O'Leary, S. (2013). Collaborations in higher education with employers and their influence on graduate employability: An institutional project. Enhancing Learning in the Social Sciences, 5(1), 37-50.

Orrell, J. (2011). Good practice report: Work-integrated learning. Strawberry Hills, NSW: Australian Learning and Teaching Council.

Owens, J., \& Tibby, M. (2014). Enhancing employability through enterprise education: Examples of good practice in higher education. UK: The Higher Education Academy.

Patrick, C.-j., Peach, D. D., Pocknee, C., Webb, F., Fletcher, D. M., \& Pretto, G. (2008). The WIL [Work Integrated Learning] report: A national scoping study [Australian Learning and Teaching Council (ALTC) Final report]. Brisbane: Queensland University of Technology.

Peach, D., Larkin, I., \& Ruinard, E. (2012). High-risk, high-stake relationships: Building effective industry-university partnerships for work Integrated learning. Paper presented at the ACEN National Conference Melbourne.

Rosenberg, S., Heimler, R., \& Morote, E.-S. (2012). Basic employability skills: A triangular design approach. Education+Training, 54(1), 7-20.

Rust, C., \& Froud, L. (2011). 'Personal literacy': The vital, yet often overlooked, graduate attribute. Journal of Teaching and Learning for Graduate Employability, 2(1), 28-40.

Sala, G. (2011). Approaches to skills mismatch in the labour market: A literature review. Papers: Revista de Sociologia(96), 1025-1045. 
Scott, P. (2005). Universities and the knowledge economy. Minerva, 43(3), 297-309.

Smith, J., Meijer, G., \& Kielly-Coleman, N. (2010). Assurance of learning: The role of work integrated learning and industry partners. In M. Campbell (Ed.), Work integrated learning: Responding to challenges (pp. 409-419). Perth, WA: Australian Collaborative Education Network (ACEN), Curtin University of Technology.

Speight, S., Lackovic, N., \& Cooker, L. (2012). Stakeholder attitudes towards employability in a Sino-British university. Journal of Teaching and Learning for Graduate Employability, 3(1), 26-40.

Sternberg, R. J., Forsythe, G., Hedlund, J., Horvath, J., Wagner, R., Williams, W., . . Grigorenko, E. (2000). Practical intelligence in everyday life. Cambridge: Cambridge University Press.

Tanaka, Y. (2009). WIL as human capital investment: An economic analysis. Paper presented at the WACE Conference in Vancouver.

Tomlinson, M. (2012). Graduate employability: A review of conceptual and empirical themes. Higher Education Policy, 25(4), 407-431.

Tomusk, V. (2004). Three Bolognas and a pizza pie: Notes on institutionalization of the European higher education system. International Studies in Sociology of Education, 14(1), 75-96.

Tran Thi Tuyet (2012). Graduate employability: Interpretation versus expectation. In N. Brown, S. M. Jones \& A. Adam (Eds.), Research and development in higher education: Connections in higher education, Vol. 35 (pp. 317-325). Hobart, Tasmania: HERDSA.

Tran Thi Tuyet. (2014). Graduate employability in Vietnam: A loose relationship between higher education and employment market. Hamburg: Anchor Academic Publishing.

Tran Thi Tuyet. (2015). Is graduate employability the 'whole-of-higher-education-issue'? Journal of Education and Work, 28(3), 207-227.

Tynjälä, P. (2008). Perspectives into learning at the workplace. Educational Research Review, 3(2), 130-154.

UK Commission for Employment and Skills. (2009). Employee demand for skills: A review of evidence \& policy - Executive summary. London: WM Enterprise and Employment Research Institute, Edinburgh Napier University.

Weisz, M., \& Smith, S. (2010). Critical changes for successful cooperative education. In A. Brew \& C. Asmar (Eds.), Higher education in a changing world: Research and development in higher education, Vol. 28, (pp. 605-615). Sydney, NSW: Higher Education Research and Development Society of Australasia (HERDSA).

Weligamage, S. S. (2009). Graduates' employability skills: Evidence from literature review. Sri Lanka: University of Kelaniya.

Wilson, T. (2012). A review of business-university collaboration. London: Department for Business, Innovation and Skills.

Winch, C. (2006). Graduate attributes and changing conceptions of learning. In P. Hager \& S. Holland (Eds.), Graduate attributes, learning and employability. Dordrecht, The Netherlands: Springer.

World Bank (2011). Putting higher education to work: Skills and research for growth in East Asia. Washington D. C: World Bank Publications.

World Bank (2012). Putting higher education to work: Skill and research for growth in East Asia (p. 195). World bank East Asia and Pacific Regional Report, Washingon DC: The World Bank. 
Yorke, M. (2006). Employability in higher education: What it is - What it is not. York: The Higher Education Academy.

Yorke, M. (2010). Employability: Aligning the message, the medium and academic values. Journal of Teaching and Learning for Graduate Employability, 1(1), 2-12.

Zegwaard, K. E., \& Coll, R. K. (2011). Using cooperative education and work-integrated education to provide career clarification. Science Education International, 22(4), 282291. 